\title{
SHAPING SOCIAL COMPETENCES AND SOCIAL CAPITAL IN CHILDREN AND ADOLESCENTS BY MEANS OF NON-FORMAL EDUCATION METHODS AND TECHNIQUES
}

\author{
MAŁGORZATA PACZYŃSKA-JĘDRYCKA, ${ }^{1}$ WIOLETTA ŁUBKOWSKA, ${ }^{2}$ \\ MARTA JONCA ${ }^{3}$
}

\begin{abstract}
${ }^{1}$ Szczecin University
e-mail: m.paczynska-jedrycka@univ.szczecin.pl

${ }^{2}$ Szczecin University e-mail: wioletta.lubkowska@univ.szczecin.pl

${ }^{3}$ Centrum Edukacji Nieformalnej i Outdooru

e-mail:marta@infocity.pl

RECEIVED

ACCEPTED

JEL

CLASSIFICATION

KEYWORDS

ABSTRACT

25 March 2015

1 June 2015

121

social competences, social capital, animation games and activities, non-formal education, physical culture, recreation

This paper is aimed at presenting an innovative method of effective education for children and adolescents in the field of social competences through animation games and activities, as well as presenting the gist of nonformal education in this process. The research showed that activities which employ the abovementioned methods and techniques (i.e. energizers, ice-breakers, team-building tasks, communication and projects games) offer a significant educational potential, which may be used to develop social competences, and - consequently - social capital. Amongst the most frequently reported benefits of shaping social competences by means of non-formal education were: cooperation skills, self-confidence, decision-making skills, overcoming shyness, ability to help others, taking care of the weak, and coping with challenging situations.
\end{abstract}

\section{Introduction}

Social capital plays a considerable role in the development of the society, thus influencing quality of life. The level of social capital in Poland has room for improvement. A social diagnosis supervised by J. Czapiński clearly proved a deficit in social capital and civil society in Poland. J. Czapiński (2013: 297) put it bluntly: 'we are living in a country full of increasingly efficient individuals and invariably inefficient society'. 
Social capital is connected with education. Nowadays, education cannot be perceived solely as factual knowledge about certain field of science. Moreover, the labor market expects the candidates to have certain social competencies (i.e. soft skills). Therefore, educators should adapt education methods to realities of the labor market from the earliest age possible of their pupils.

The available literature lacks a clear and common definition of social competences (Łubkowska, 2014). Number of definitions is equal to number of researchers exploring this issue. Current approach suggests that social competences are a general ability of an individual to interact with their surroundings and achieve their goals (individual or group goals) while following the accepted norms. Social competences include: exerting social influence, getting to know other people, helping others, cooperation, team building and leading, communication, auto-presentation, and reacting to conflicts (Kształtowanie..., 2011).

According to A. Matczak (2001: 7), social competences are 'complex skills which condition the effectiveness of coping with certain social situations, acquired by an individual in the course of social training'. These include: selfawareness (in its broad sense), decision-making skills and noticing consequences of decisions, controlling one's emotions, and empathy (Goleman, 1995). M. Jurevičienè et al.'s team (2012: 47) proposed the following division of competences: '(1) cooperation skills, (2) communication skills, (3) participation skills, (4) emotional skills, (5) social cognition skills'. No matter which classification is used, social competences may be understood as a set of skills which help an individual socialize and adapt to ever-changing surroundings and people. It may be, therefore, said that the higher social competences, the easier life.

Importantly, physical culture - even in its broadest sense - does not focus solely on increasing physical agility. The definition of physical education by Osiński highlights both the physical aspect of the human body, as well as its role in shaping social competences (Paczyńska-Jędrycka and Łubkowska, 2014). Osiński also proposed his own view on aims of physical education, and highlighted such aspects as: fair play, shaping practical life skills and ability to co-exist with others (Osiński, 2011). It is, then, justified to connect the process of physical education with shaping social competences. One cannot, for example, play basketball without the ability to cooperate in a group or respecting other people (both own teammates and opponents).

One is accompanied by the process of physical education in its broadest from an early stage of life. It must be emphasized that physical education does not only teach how to move or how to play football. It is a process which shapes certain attitudes, including discipline, order, self-esteem, cooperation skills, independence, selfassessment and self-control. It teaches to be sensitive to the needs of others and encourages to help them. It is a life-long process (provided an individual does not resign from physical activity). It improves both physical skills and social competences, which are increasingly more valued in a society, both in private and professional/sports life (Budzyńska and Ali Aziz Dawood Al Sudani, 2013).

'Good practice' instilled at school and cultivated at a later stage of development or in professional life, is noticed and valued by employers. Panasiuk (2014) emphasizes the role of social capital in business management. Therefore, it is vital to incorporate 'soft skills' into all stages of education.

K. Denek (2008: 8) wrote: 'A school of tomorrow is a process of constant effort, knowledge, and imagination of teachers, students and their parents. It prepares them do live in a world which values creativity and resourcefulness for a common good. It instills a sense of self-esteem in adolescents. It is a state of mind which is a foundation for life competences.' Considering the above, one may want to ask: is reconstructive knowledge sufficient to navigate 
in the contemporary world? Or perhaps the knowledge combined with practical life abilities are superior values for an individual?

This article is aimed at presenting the role of non-formal education in shaping social competences of children and adolescents.

\section{Methods}

The research was conducted during a training session in Latvia, in May 2014, which was a part of the Grundtvig Partnership Project "Non Formal and Formal Partnership in Adult Education" (Grundtvig Reference Number 2013-R01-GRU06-29569 2).

The research used diagnostic polling method, which was accompanied by the following techniques: survey and observation. The questionnaire included 15 questions and respondents' particulars. In this article, however, 8 questions were analyzed. One of them was a half-open question, one was a single-choice question, and the remaining six were multiple-choice questions. The questionnaire was developed by observing activities (including games and animation activities) during previous project meetings, which took place in Czarnocin (Poland) and Drobeta-Turnu Severin (Romania). Observations and authors' own experiences helped to select the recommended games and animation activities.

The research included 16 trainers of non-formal education from Greece (12.5\%), Latvia (68.75\%), Poland $(6.25 \%)$ and Romania (12.5\%). Majority of respondents participated in previous project meetings. A vast majority of trainers had years of experience in their role. It was supported by observation carried out during training, and the results are presented in Table 1. Majority of trainers (62.5\%) enrich non-formal education with animation games, as well as outdoor techniques for more than 5 years, while $12.5 \%$ of them have just started their path in that regard.

Table 1. Trainers' years of experience in non-formal education (incl. animation games and outdoor techniques)

\begin{tabular}{lr}
\hline \multicolumn{1}{r}{ Years } & $\%$ \\
\hline Just started & 12.50 \\
1 year & 12.50 \\
2 years & 0.00 \\
3 years & 6.25 \\
4 years & 0.00 \\
5+ years & 62.50 \\
Other & 6.25 \\
\hline
\end{tabular}

Source: based on authors own study.

\section{Results}

Modern lifestyle pushes educators towards seeking new and valuable forms of education. Energizers are games aimed at physical or mental activation (depending on the nature of a particular activity). They generate good atmosphere, stimulate participants into further actions (Training Guide..., 2004) and provide a break from e.g. a monotonous lesson. These benefits were reflected in the research (Table 2). 
Table 2. Benefits of energizers (\%)

\begin{tabular}{lcc}
\hline \multicolumn{1}{c}{ Benefits } & $\begin{array}{c}\text { Children } \\
(3-12 \text { years })\end{array}$ & $\begin{array}{c}\text { Adolescents } \\
(13-18 \text { years })\end{array}$ \\
\hline Relaxing group members & 37.5 & 31.3 \\
Introducing good atmosphere & 81.3 & 75.0 \\
Stimulating into action & 50.0 & 68.8 \\
Integration & 50.0 & 75.0 \\
Other & 12.5 & 12.5 \\
\hline
\end{tabular}

Note: as subjects could choose more than one answer, the sum is higher than $100 \%$.

Source: based on authors own study.

According to trainers, energizers primarily introduce good atmosphere in groups of children and adolescents (children: $81.3 \%$, adolescents: $75 \%$ ). Other popular answers were: integration (children - 50\%, adolescents - 75\%), stimulating into action (children - 50\%, adolescents - 68.8\%) and relaxing (children - 37.5\%, adolescents - 31.3\%). Energizers are worth using in the classroom as 'interludes', so that children and adolescents can start or continue work with an increased efficiency.

Ice-breakers play a significant role in group building, as long as the trainer establishes clear goals and uses adequate techniques. It is important that children and adolescents who take part in these activities overcome their fears and become more open to others and feel more at ease (Dennick and Spencer, 2011). A. Umaday (2013) also underlines the importance of overcoming barriers. Undoubtedly, it promotes a better and more relaxed atmosphere in a group. Benefits of these activities are presented in Table 3.

Table 3. Benefits of ice-breakers (\%)

\begin{tabular}{lcc}
\hline \multicolumn{1}{c}{ Benefits } & $\begin{array}{c}\text { Children } \\
\text { (3-12 years) }\end{array}$ & $\begin{array}{c}\text { Adolescents } \\
\text { (13-18 years) }\end{array}$ \\
\hline Chance to meet other people & 56.3 & 68.8 \\
Breaking barriers between people & 87.5 & 81.3 \\
Integration & 62.5 & 68.8 \\
Other & 12.5 & 6.3 \\
\hline
\end{tabular}

Note: as subjects could choose more than one answer, the sum is higher than $100 \%$.

Source: Based on authors own study.

According to trainers who use non-formal education at work, the most common benefit is overcoming barriers amongst children (87.5\%) and adolescents (81.3\%). The second most commonly reported benefit was integration (children $62.5 \%$, adolescents $68.8 \%$ ). A chance to meet others came third $(56.3 \%)$ for children, while amongst adolescents it gave a result identical to integration.

Team-building activities are aimed at creating a team. These activities and games are based on cooperation (Bond, 2012; Margulis, 2005). Effects of team-building activities depend on the age group (Table 4).

For children, team-building activities primarily build a sense of security (81.3\%). Trainers also pointed to other common effects: integration (62.5\%), knowing how to cooperate (56.3\%), and leading to conflicts (56.3\%). In case 
of adolescents, trainers pointed mainly to cooperation (87.5\%), and secondly, assigning roles in a group. Third place was occupied jointly by two effects: introducing good atmosphere (75\%) and leading to conflicts (75\%). Teambuilding activities may lead to conflicts in a group because of problem-based tasks. A trainer prepares an adequate educational background and assigns a group to a task which - through conflicts and its solution - may increase team members' social skills. Conflict occurs most frequently when group consists of strong personalities who all want to be a leader. One should not intervene in such situation, but be able to skillfully use this element during the summary.

Tahle 4. Benefits of team-building activities (\%)

\begin{tabular}{lcc}
\hline \multicolumn{1}{c}{ Benefits } & $\begin{array}{c}\text { Children } \\
(3-12 \text { years })\end{array}$ & $\begin{array}{c}\text { Adolescents } \\
(13-18 \text { years })\end{array}$ \\
\hline Teaching how to cooperate & 56.3 & 87.5 \\
Introducing good atmosphere & 25.0 & 75.0 \\
Integration & 62.5 & 62.5 \\
Assigning roles in a group & 50.0 & 81.3 \\
Building a sense of security & 81.3 & 62.5 \\
Leading to conflicts & 56.3 & 75.0 \\
Forcing to leave the comfort zone & 31.3 & 31.3 \\
Breaking the barrier of touch & 50.0 & 56.3 \\
Other & 12.5 & 12.5 \\
\hline
\end{tabular}

Note: as subjects could choose more than one answer, the sum is higher than $100 \%$.

Source: based on authors own study.

Teambuilding activities also include communication games (Table 5) and projects games (Table 6).

Table 5. Benefits of communication games (\%)

\begin{tabular}{lcc}
\hline \multicolumn{1}{c}{ Benefits } & $\begin{array}{c}\text { Children } \\
(3-12 \text { years })\end{array}$ & $\begin{array}{c}\text { Adolescents } \\
\text { (13-18 years) }\end{array}$ \\
\hline Teaching cooperation & 75.0 & 81.3 \\
Integration & 62.5 & 81.3 \\
Teaching openness to others & 56.3 & 56.3 \\
Chance to appoint a leader & 56.3 & 87.5 \\
Chance to assign tasks to group members, based on their skills & 56.3 & 43.8 \\
Encouraging difficult conversations on sensitive topics & 12.5 & 43.8 \\
Teaching speaking, listening, reasoning & 68.8 & 68.8 \\
Forcing to adapt to requirements of a situation & 62.5 & 68.8 \\
Other & 0.0 & 0.0 \\
\hline
\end{tabular}

Note: as subjects could choose more than one answer, the sum is higher than $100 \%$.

Source: Based on authors own study.

In children, these activities mainly teach cooperation (75\%), as well as speaking, listening and reasoning (68.8\%). Undoubtedly, these games force participants to adapt to certain situations $(62.5 \%)$, and facilitate 
integration. In adolescents, the following benefits were frequent: chance to appoint a leader (87.5\%), cooperation $(81.3 \%)$, integration (81.3\%), and teaching how to speak, listen and reason. The least common benefit in both groups was 'encouraging difficult conversations on sensitive topics'. Project-based games are very time-consuming. Their benefits are presented in Table 6 .

Table 6. Benefits of project-based games (\%)

\begin{tabular}{lcc}
\hline \multicolumn{1}{c}{ Benefits } & $\begin{array}{c}\text { Children } \\
(3-12 \text { years })\end{array}$ & $\begin{array}{c}\text { Adolescents } \\
\text { (13-18 years) }\end{array}$ \\
\hline Teaching cooperation & 68.8 & 68.8 \\
Integration & 50.0 & 68.8 \\
Teaching how to make decisions & 43.8 & 75.0 \\
Chance to appoint a leader & 43.8 & 62.5 \\
Chance to assign tasks to group members, based on their skills & 37.5 & 56.3 \\
Chance to test one's ability to act in emergencies & 37.5 & 43.8 \\
Challenge for the group & 25.0 & 75.0 \\
Chance for a group to prove themselves in difficult conditions & 31.3 & 31.3 \\
Orientation on goal & 56.3 & 56.3 \\
Forcing the use available resources in a purposely prepared educational & 37.5 & 56.3 \\
situation & & 6.3 \\
Other & 0.0 & \\
\hline
\end{tabular}

Note: as subjects could choose more than one answer, the sum is higher than $100 \%$.

Source: based on authors own study.

Trainers reported that amongst children, these activities first and foremost taught cooperation (68.8\%). Achieving an objective was also frequently reported (56.3\%). Surely, the aim is to show children that every action has a clear goal which needs to be achieved while overcoming obstacles. For adolescents, the project-based method helped develop the following soft skills: decision-making (75\%), facing challenges $(75 \%)$, cooperation (68.8\%), integration (68.8\%), and a chance to appoint a leader (62.5\%).

Irrespectively of the age group where methods and techniques of non-formal education were used, the trainers agreed that they help develop individual's social competences (Tables 7 and 8 ).

Table 7. Development of social competences by means of non-formal education

\begin{tabular}{cc}
\hline Development of social competences & $\%$ \\
\hline Yes & 100 \\
No & 0 \\
\hline
\end{tabular}

Source: based on authors own study.

Majority of trainers agreed that using methods and techniques of non-formal education allowed individuals to cooperate (93.8\%). Active participation resulted in an increase in self-confidence (87.5\%). Participants also developed decision-making skills (62.5\%). Some participants overcame their shyness and felt the need to help others. 
Table 8. Social competences developed through non-formal education

\begin{tabular}{lc}
\hline Social competences & $\%$ \\
\hline Ability to cooperate & 93.8 \\
Self-confidence & 87.5 \\
Ability to make decisions & 62.5 \\
Overcoming shyness & 56.3 \\
The need to help others & 56.3 \\
Openness to others & 50.0 \\
Ability to cope with difficult situations (stress, threats) & 43.8 \\
Assertiveness & 25.0 \\
\hline
\end{tabular}

Note: as subjects could choose more than one answer, the sum is higher than $100 \%$.

Source: based on authors own study.

\section{Discussion}

According to the current education law, school education should prepare the student not only to move to the next stage of education, but also to equip them with practical life skills. According to B. Woynarowska (2013), shaping life skills is an important element of physical education. 'Shaping life skills at school is not a fad; it is required by the Convention on the Rights of the Child' (Woynarowska, 2013: 452).

Unfortunately, formal education has been deprived of its most valuable asset: ensuring a good start on the labor market. If schools were able to teach active citizenship, non-formal education may not be needed. Alas, it does not teach it. For many young people, non-formal education is the only chance for individual development and acquisition of skills and knowledge. Therefore, it does not matter whether learning is pleasant, innovative, or stressful because good grades - although still greatly desired - do not guarantee a successful work life any more (Kaczanowska, 2005).

Undoubtedly, non-formal education in Poland is still in its infancy. It is used intuitively, is neither ordered nor named. Often the hidden goal of activities is random, and its potential is not used to the fullest. Nevertheless, it is an important element in the process of educating children, adolescents and adults. Hence, there is an increasing need for training co-financed by the European Union. Today's students and pupils should not only have factual knowledge. The process of education must equip them with certain skills and social competences needed for successful life. Considering the requirements expected from candidates on the current labor market, willingness to take up challenges, assertiveness, team-playing skills are among competencies which should be taught to children from an early stage of life. Trainers, instructors and animators (including these working with socially maladjusted adolescents) are faced with a great challenge: to teach methods and techniques of non-formal education to teachers. Their input is especially needed in terms of offering a broad spectrum of games and activities which may be used with groups of students. Kozdron (2014) described examples of games and activities which help develop social competences. Considering physical culture perspective and WHO's recommendations, these games and activities should involve movement. They should not, however, serve as 'time-killers'. It is necessary to discuss the tasks upon their completion, which serves as a chance for participants to communicate their thoughts and overcome shyness. 
Educating an individual (not only in terms of factual knowledge) from an early stage of life is necessary for a brighter future. Modern educators, physical culture animators and recreation animators should highlight the importance of games and activities. These games and activities, however, should not be understood as competitive sports activities, e.g. throwing, running, jumping, but rather as energizers, ice-breakers, team-building tasks (Paczyńska-Jędrycka, Frąckowiak and Łubkowska, 2014), communication and projects games. Importance of games and activities was emphasized by M. Pivec and O. Dziubenko (2004), who highlighted cooperation within group and development of decision-making skills. Additionally, the authors stated that the modern labor market expects the candidates to possess a broad range of soft skills, such as sense of responsibility, communication skills, creativity and team-playing skills. It needs to be remembered that people learn the quickest when learning is fun. Pedagogically speaking, this may be confronted with the chain of pedagogical life experience, which is made of four elements: "(1) events, impressions, (2) sensations, (3) experiences, (4) cognition" (Michl, 2011: 13). According to the author, the pedagogy of life experiences does not need to relate to sports or outdoor activities; it can be a simple game which constitutes an event for children and adolescents. Through games, an individual obtains experiences used to draw adequate conclusions. Thus, games/activities serve as a chance for an individual to learn something new (incl. about themselves). Every activity (irrespective of its nature) should be properly summarized by the trainer, teacher or animator. This may lead to beneficial results, such as permanent changes in behavior and attitudes of children and adolescents, and consequently, in adults.

\section{Conclusions}

The research showed that:

1. The effects of skill improvement initiatives which used non-formal education methods and techniques in the education process (energizers, ice-breakers, team-building tasks, communication and project games) included: improved cooperation skills, communicativeness, overcoming barriers between people, integration, improved negotiation skills, decision-making, as well as improved adaptability to new situations.

2. The effects of attitude improvement initiatives which used non-formal education methods and techniques in the education process, included: openness to other people and various social situations, respect, and empathy.

3. Amongst the most frequently reported benefits of shaping social competences by means of non-formal education were: cooperation skills, self-confidence, decision-making skills, overcoming shyness, ability to help others, taking care of the weak, openness to others, and coping with challenging (stressful, threatening) situations.

\section{References}

Bond, N. (2012). Key Success Factors for Effective Team-Building Activities. AMWA Journal, 3 (27): 129-131.

Budzyńska, K. \& Ali Aziz Dawood Al Sudani (2013). Inteligencja emocjonalna - kobiet i mężczyzn w pierwszej lidze koszykówki. Wychowanie Fizyczne i Zdrowotne, 7: 28-31.

Czapiński, J. (2013). Kapitał społeczny. In: Diagnoza Społeczna 2013. Warunki i Jakość Życia Polaków - Raport. Eds. J. Czapiński, T. Panek, [Special issue]. Contemporary Economics: 285-298. Available at: www.diagnoza.com (accessed on 4.03.2015).

Denek, K. (2008). Edukacja jutra. Homines Hominibus. 1 (4). Available at: www.homines.wspia.pl/pdf/2008/Homines2008_01_Denek. pdf (accessed on 2.02.2014). 
Dennick, R. \& Spencer, J. (2011). Teaching and learning in small groups. In: T. Dornan, K. Mann, A. Scherpbier, J. Spencer. Medical Education. Theory and Practice. Integrates practice, theory, innovation and research. Churchill Livingstone Elsevier. Available at: www.books.google.pl/books?id=qUHFAAAAQBAJ\&pg=PT505\&dq=theory+of+icebreakers\&hl=pl\&sa=X\&ei=ToLSVMfMM4K vUYWSgqAJ\&ved=0CCgQ6AEwAQ\#v=onepage\&q=theory\%20of\%20icebreakers\&f=false (accessed on 4.02.2015).

Goleman, D. (1995). Inteligencja emocjonalna. Poznań: Media Rodzina of Poznań.

Jurevičienè, M., Kaffemanienè, I. \& Ruškus J. (2012). Concept and structural components of social skills. Education. UGDYMAS, KŪNO KULTŪRA, SPORTAS, 3 (86): 42-52, SOCIALINIAI MOKSLAI.

Kaczanowska, J. (2005). Doświadczać uczenia. Warszawa: Fundacja Rozwoju Systemu Edukacji. Avaliable at: www.mlodziez.org. pl/sites/mlodziez.org.pl/files/publication/205/doswiadczac_uczenia_materialy_pokonferencyjne_pdf_90786.pdf (accessed on 12.03.2015)

Kozdroń, A. (2014). Scenariusze zajęć i zabaw dla wychowanków, pedagogów, animatorów kultury i rodziców. Warszawa: DIFIN SA.

Kształtowanie się kompetencji społecznych w procesie edukacji pozaformalnej w ramach trzeciego sektora oraz pozasektorowych inicjatyw edukacyjno-społecznych w Polsce (2011). Projekt systemowy „Opracowanie założeń merytorycznych i instytucjonalnych wdrażania Krajowych Ram Kwalifikacji oraz Krajowego Rejestru Kwalifikacji dla uczenia się przez całe życie”. Warszawa: Instytut Badań Edukacyjnych.

Łubkowska, W. (2014). Pedagogika obozów letnich w programach kształcenia studentów kierunku wychowanie fizyczne oraz turystyka i rekreacja - realizowanych na Wydziale Kultury Fizycznej i Promocji Zdrowia Uniwersytetu Szczecińskiego. Aktywność Ruchowa Ludzi w Różnym Wieku, 1-4 (21-24): 21-30.

Margulis, L (2005). Gry w wirtualnym środowisku nauczania. E-mentor, 1 (8): 83-87. Avaliable at: www.e-mentor.edu.pl/_pdf/ementor8. pdf\#page=83 (accessed on 13.03.2015).

Matczak, A. (2001). Kwestionariusz Kompetencji Społecznych KKS. Warszawa: Pracownia Testów Polskiego Towarzystwa Psychologicznego.

Michl, W. (2011). Pedagogika przeżyć. Kraków: Wydawnictwo WAM.

Osiński, W. (2011). Teoria wychowania fizycznego. Poznań: AWF.

Paczyńska-Jędrycka, M. Frąckowiak, P. \& Łubkowska, W. (2014). Leisure Time animation in the context of rehabilitation of juveniles in youth detention centres/correctional facilities. Centr Eur J Sport Sci Med., 8 (4): 115-122.

Paczyńska-Jędrycka, M. \& Łubkowska, W. (2014). Edukacja zdrowotna przez gry i zabawy ruchowe z uwzględnieniem zabaw animacyjnych w opinii studentek pedagogiki elementarnej (na przykładzie województwa wielkopolskiego). Pielęgniarstwo Polskie, 3 (53): 215-221.

Panasiuk, A. (2014). Selected Issues of Management of Regional Tourist Product. Zeszyty Naukowe Uniwersytetu Szczecińskiego. Scientific Journal. Service Management, 12: 47-58.

Pivec, M. \& Dziubenko, O. (2004). Game-Based Learning in Universities and Lifelong Learning: “UniGame: Social Skills and Knowledge Training" Game Concept. Journal of Universal Computer Science, 1 (10): 14-26. Available at: http://jucs.org/jucs_10_1/game_ based_earning_in/Pivec_M.pdf (accessed on 4.02.2015).

Training Guide and Training Techniques, (2004). UNESCO Asia and Pacific Regional Bureau for Education, Bangkok. Available at: http://unesdoc.unesco.org/images/0013/001356/135603e.pdf (accessed on 4.02.2015).

Umaday, A. (2013). The Magic of "Ice breakers". Modern Athlete \& Coach, 1 (51): 7-10.

Woynarowska, B. (2013). Edukacja zdrowotna. Warszawa: Wydawnictwo Naukowe PWN.

Cite thiß anticle aS: Paczyńska-Jędrycka, M., Łubkowska, W., Jońca, M. (2015). Shaping social competences and social capital in children and adolescents by means of non-formal education methods and techniques. Szczecin University Scientific Journal, No. 872. Service Management, 15 (1): 67-75. 
